$\left\{\begin{array}{l}\text { J.M.J., Vol. 4, No. } 5 \\ \text { October, } 1951\end{array}\right]$

\title{
NEUTRALIZATION TEST OF ANIMAL SERA COLLECTED \\ IN JAPAN AGAINST POLIOMYELITIS VIRUS \\ LANSING STRAIN
}

\author{
MASAMI KITAOKA and TEIJI MIURA \\ National Institute of Health, Tokyo, Japan
}

Now it is well known that viruses which cause paralytic poliomyelitis are not immunologically unique but are divided into at least three immunologically different types, Brunhilde, Lansing and Leon (Bodian). Recent investigations on non-paralytic polio revealed that polio viruses in a broader sense may include Coxsackie viruses, Col-SK group viruses and some other groups of viruses in addition to the above mentioned 3 types of virus.

Among these 3 paralytic polio viruses, the existence of Lansing type polio virus in Japan was confirmed by positive neutralization test of human sera, collected in various parts of Japan, against the polio virus Lansing strain 1. 2), and by the isolation of a new Lansing type polio virus "B 34 " strain in Tokyo, which was identified with Lansing strain ${ }^{3}$. The existence of the other types of polio viruses in Japan will be reported in a separate paper.

As for the specificity of the neutralizing substances against polio virus contained in the sera tested, it may reasonably be assumed that most of them were produced specifically after invasion of the virus; this problem will be discussed later in this report. If the above assumption is correct, detection of neutralizing antibodies in animal sera will reasonably serve to support the presumption of the existence of polio virus in Japan, and also to estimate the epidemiological significance of these animals in human poliomyelitis.

The present study was planned to give some explanations on these problems, and also to discuss the specificity of neutralizing antibodies.

\section{MATERIALS AND METHOD}

Neutralization tests against the polio virus Lansing strain were performed with animal sera, collected in Tokyo and its vicinity in 1947-48 (37 cattle, 11 horses, 6 sheep, 5 goats, 8 rabbits, 7 guinea pigs, 8 roof rats. 
4 mice, 21 birds and 4 toads ; 111 specimens in total) and in Hachinoe City, Aomori Prefecture, which was then under a large epidemic in June 1949 (5 pigs, 10 horses, 3 cattle and 6 sheep; 24 specimens in total).

The majority of these sera was used at first for the complement fixation and neutralization tests with Japanese $B$ encephalitis (JBE) virus, and then had been stored under refrigeration $\left(4-10^{\circ} \mathrm{C}\right)$ during $3-10$ months until used for the neutralization test with polio virus. The procedures for neutralization test are the same as were described in the preceding report ${ }^{1}$.

\section{RESUL'TS}

\section{Neutralization test}

The results of neutralization tests on the animal sera collected in Tokyo and Hachinoe are shown in Table 1. Among the animal sera collected in

Table 1.

Neutralization test with animal sera against

Lansing strain

\begin{tabular}{|c|c|c|c|c|c|c|}
\hline Location & Animal & $\begin{array}{c}\text { Neut } \\
0-1.4 \\
-\end{array}$ & $\begin{array}{c}\text { lization } \\
1.5-1.9 \\
\pm\end{array}$ & $\begin{array}{c}\text { index } \\
2.0-+ \\
+\end{array}$ & Total & $\begin{array}{l}\text { Positive } \\
\text { rate in \% }\end{array}$ \\
\hline \multirow{10}{*}{ Tokyo } & Cattle & 5 & 16 & 16 & 37 & 43 \\
\hline & Horse & 5 & 5 & 1 & 11 & 9 \\
\hline & Sheep & 1 & 3 & 2 & 6 & 33 \\
\hline & Goat & 2 & 3 & 0 & 5 & 0 \\
\hline & Rabbit & 7 & 1 & 0 & 8 & 0 \\
\hline & Guinea-pig & 4 & 2 & 1 & 7 & 14 \\
\hline & Roof rat & 8 & 0 & 0 & 8 & 0 \\
\hline & White mouse & 4 & 0 & 0 & 4 & 0 \\
\hline & Birds* & 11 & 8 & 2 & 21 & 10 \\
\hline & Toad & 3 & 0 & $1 * *$ & 4 & 25 \\
\hline \multirow{4}{*}{ Hachinoe } & Pig & 0 & 1 & 4 & 5 & 80 \\
\hline & Cattle & 2 & 1 & 0 & 3 & 0 \\
\hline & Horse & 1 & 4 & 5 & 10 & 50 \\
\hline & Goat & 4 & 2 & 0 & 6 & 0 \\
\hline
\end{tabular}

* Twenty-one birds consist of 5 domestic fowls (Gallus gallus var, domesticus), 9 domestic ducks (Anas platyrhyncha var. domestica), 3 white fronted geese (Anser albifrons), 2 hooded cranes (Grus monacha), one eastern bean-goose (Anser fabalis serrirostris) and one muscovy duck (Cairina moschata). Among them, one domestic fowl and one eastern bean-goose showed positive neutralization test.

** Retested 3 months later and confirmed. 
Tokyo, roof rats and mice demonstrated completely negative results: none of the rabbits or goats did positive results, but it is interesting that sheep, guinea pig, horse and cattle showed positive neutralization tests in $33 \%$, $14 \%, 9 \%$ and $43 \%$ respectively.

Among 4 toads, one showed definitely positive results, this toad has previously been inoculated with JBE virus intraperitoneally 10 times in every 5 days and bled 20 days after the last inoculation, consequently its serum contained neutralizing antibodies against JBE virus ${ }^{4}$ ). Two of the remaining 3 toads, which had previously been inoculated with JBE virus in a similar manner, showing positive neutralization reaction against JBE virus, and one remaining one, which had been left untreated showing negative result in neutralization test against JBE virus, did not demonstrate any evidence of the presence of neutralizing antibodies against polio virus Lansing strain.

Among 21 birds' sera collected in Ueno Zoo and in some other places near Tokyo, only 2 showed positive neutralization test (one domestic fowl and one eastern bean goose). On the other hand, among 9 domestic ducks, 7 were completely negative and only 2 were equivocal.

Among animal sera collected in Hachinoe City, Aomori Prefecture, 3 cattle were negative or equivocal; 5 out of 6 horses, and 4 out of 5 pigs were positive. A certain difference was in the positive rates among cattle in Hachinoe City, though only 3 in number, and in Tokyo, where the rate was found to be quite high. Six goats were negative or equivocal identically with the results in Tokyo.

\section{Age distribution of noutralizing antibodies}

When the results of neutralization tests with cattle sera, which showed the highest positive rate among animal sera collected in Tokyo, are tabulated according to ages as shown in Table 2, none of the calves under 6 months of age demonstrate positive result, but 2 out of 6 (33\%) are positive in 1-2 years group, and more than $50 \%$ are positive in the cattle more than 3 years group. In short, the older the cattle are the higher the positive rates of neutralizing antibodies are in them. This phenomenon may be better understood to be due to the specific antibody formation by the repeated invasion of polio virus, rather than due to non specific virucidal substances, which might increase with ages. This interpretation is also supported by the negative results with cattle sera collected in 
Hachinoe. However, the question as to whether all of the neutralizing substances are specific or not is still remained open. The existence of certain labile neutralizing substances proved in animal sera are described in the next chapter in this paper.

Table 2.

Ago distribution of neutralizing antibodies in castlo sern, colleeted in the vicinity of Tokyo, agrainst Lansing strain

\begin{tabular}{|c|c|c|c|c|c|}
\hline Age & $\begin{array}{c}\text { Neut } \\
0-1.4 \\
-\end{array}$ & $\begin{array}{c}\text { alization } \\
1.5-1.9 \\
\pm\end{array}$ & $\begin{array}{c}\text { index } \\
2.0- \\
+\end{array}$ & 'Total & $\begin{array}{c}\text { Positive rate } \\
\text { in } \%\end{array}$ \\
\hline $0-6$ months & 3 & 3 & 0 & 6 & 0 \\
\hline $7-12$ & 0 & 0 & 0 & 0 & \\
\hline 1- 2 year & 1 & 3 & 2 & 6 & 33 \\
\hline $3-6$ & 1 & 4 & 7 & 12 & 58 \\
\hline $7-11$ & 0 & 6 & 7 & 13 & 54 \\
\hline TOTAL & 5 & 16 & 16 & 37 & 43 \\
\hline
\end{tabular}

Labile neutralizing substance in animal sera

The existence of certain labile neutralizing substance against Lansing strain in the serum from animals, especially from cattle, which is destroyed merely by 1-6 months' preservation under refrigeration or by heating for 30 minutes at $56^{\circ} \mathrm{C}$ (Hammon $\left.{ }^{\prime)}\right)$ is well known. For that, 37 sera from cattle were examined for such substance.

Group I consists of 19 cattle sera collected in July-October 1947 in the vicinity of Tokyo, and stored more than 5 months under refrigeration $\left(4-10^{\circ} \mathrm{C}\right)$ until used for neutralization test against Lansing strain. Further, some of them were stored under refrigeration and tested again 3 months later. Group II consists of 18 cattle sera taken from 9 pairs of calves and their mother cows in May 1948, and tested once 1 week and again 1 month after bleeding. Results are shown in Table 3 .

When compared the results of the 1st and 2nd test of Group I, the difference in neutralization index is less than 0.2 , and seems to be within the experimental error, in each of the 4 cases. From the above results, it is presumed that certain labile neutralizing substances, if it ever were 
Table 3.

Neutralization test with cattle sera pariormed various periods after bleeding

\begin{tabular}{|c|c|c|c|c|c|c|c|c|}
\hline \multirow{2}{*}{ Group } & \multirow{2}{*}{ No. } & \multirow{2}{*}{ Age } & \multicolumn{3}{|c|}{ Date } & \multicolumn{2}{|c|}{ Neutralization } & \multirow{2}{*}{$\begin{array}{l}\text { index } \\
\text { e) } \\
a-b\end{array}$} \\
\hline & & & Bleeding & $\begin{array}{l}1 s t \\
t \cos t\end{array}$ & $\begin{array}{l}2 n d \\
\text { test }\end{array}$ & a) 1 test $^{t}$ & $\begin{array}{l}\text { b) 2nd } \\
\text { test }\end{array}$ & \\
\hline \multirow{4}{*}{ I } & 1 & $\begin{array}{c}\text { year } \\
1\end{array}$ & 9/July 1947 & 4/Feb. 1948 & 28/Apr. 1948 & 1.95 & 1.75 & 0.20 \\
\hline & 2 & 2 & $"$ & $"$ & $"$ & 2.05 & 1.95 & 0.10 \\
\hline & 3 & 3 & 22/Aug. 1947 & $"$ & $"$ & 2.07 & 1.89 & 0.18 \\
\hline & 4 & 5 & 10/Oct. 1947 & $"$ & $"$ & 1.95 & 1.89 & 0.06 \\
\hline \multirow{12}{*}{ II } & 1 & 4.5 & 6/May 1948 & 13/May 1948 & 4/Jun. 1948 & 2.00 & 1.32 & 0.18 \\
\hline & $1^{\prime}$ & 0.6 & $"$ & $"$ & $"$ & 2.00 & 1.52 & 0.48 \\
\hline & 2 & 9.6 & $”$ & $"$ & $"$ & 1.80 & 1.67 & 0.13 \\
\hline & $2^{\prime}$ & 0.4 & $"$ & $"$ & $"$ & 1.58 & 0.82 & 0.76 \\
\hline & 3 & 7.6 & $"$ & $"$ & $"$ & 2.37 & 2.31 & 0.06 \\
\hline & $3^{\prime}$ & 0.3 & $"$ & $"$ & $"$ & 2.00 & 1.31 & 0.69 \\
\hline & 4 & 4.7 & $"$ & $"$ & $"$ & 1.75 & 1.79 & -0.04 \\
\hline & $4^{\prime}$ & 0.6 & $"$ & $n$ & $"$ & $<1.50$ & 1.92 & -0.42 \\
\hline & 5 & 3.7 & $"$ & $"$ & $"$ & 2.25 & 1.67 & 0.58 \\
\hline & $5^{\prime}$ & 0.6 & $"$ & $"$ & $"$ & 2.50 & 1.92 & 0.58 \\
\hline & 6 & 8.4 & $"$ & $"$ & $"$ & 1.88 & 1.52 & 0.35 \\
\hline & $6^{\prime}$ & 0.2 & $"$ & $"$ & $"$ & 1.75 & 1.31 & 0.44 \\
\hline
\end{tabular}

Note: The figures 4.5 or 9.6 in the colunin for Age indicate 4 years 5 month and 9 years 6 months respecivuly.

there, have disappeared already during 5 months' storage prior to the 1st test. As regards the results of Group II, the results on only 6 pairs of them, the age of their calves of which are under 1 year old, are shown in Table 3. There are marked differences between results of the 1st and 2 nd tests. The results with 5 pairs of Group II, especially their calves, showed marked decrease in their neutralization indices. The grade of decrease during 1 month's preservation was much higher in their calves than in their mother cows. Their differences are more than 0.4 in all cases. In 4 cases they are less than 0.2 which lies within the experimental error. 
In one of the calves marked increase of neutralization index was noticed after the storage; mother cow also showed an increase though it was insignificantly slight (0.04).

From these results it was concluded that certain virus neutralizing substances against Lansing strain, which disappear gradually during about one month's storage under refrigeration, were detected in cattle sera. These substances are found more frequently and in much higher concentration in the cases of younger animals, especially in the cases under one year of age. In some instances, there may also be found some neutralization inhibiting substances, which also disappear during storage within one month, as one of the sera examined showed a higher neutralization index after the storage than prior to the storage.

\section{Neutralizing antibody in milk}

Neutralization tests were made also with milk from 9 mother cows of the above calves. The results are summarized in Table 4 . Two samples of milk, which showed equivocal results in the first test, were completely negative when retested 1 month later. But one milk showed positive neutralization index in both tests. The calf of this mother cow was 2 years and 2 months old, and the serum from this calf showed equivocal neutralization index.

Table 4.

Summary of the neutralization test with cow's milk

\begin{tabular}{|cccc|}
\hline $\begin{array}{c}\text { Neutralization } \\
\text { index }\end{array}$ & $\begin{array}{c}\text { 1st test } \\
\text { 13/Miy }{ }^{\prime} 48\end{array}$ & $\begin{array}{c}\text { 2nd test } \\
\text { 4/Jun. }\end{array}{ }^{4} 4$ \\
\hline $2.0+\quad+$ & 1 & 1 \\
$1.5-1.9 \quad \pm$ & 2 & 0 \\
$0-1.4$ & - & 6 & 8 \\
\hline Total & 9 & 0 \\
\hline
\end{tabular}

\section{DISCUSSION}

The positive results of neutralization tests against Lansing strain with sera taken from various animals in Tokyo and Hachinoe, which are according with the positive results with human sera in the same areas, may 
be expounding the fact that these areas are infested generally with Lansing strain virus. These animals seem to have been also subclinically infected and developed neutralizing antibodies against Lansing virus.

Cattle showed negative neutralizing antibodies in Hachinoe, while they showed a high positive rate in Tokyo, and further, the older the cattle are the higher the positive rate is. These facts indicate that cattle are infected during their growth and becoming positive in neutralization test to polio virus. Therefore, it is suspected that certain correlation may exist between cow milk and some epidemic of poliomyelitis in Tokyo.

Horses, however, which showed very low positive rate in Tokyo, showed much higher rate in Hachinoe. In Hachinoe, horses and pigs showed a high positive rate. The cause of difference in neutralization test positive species of animal in Tokyo and in Hachinoe is quite obscure. However, the difference in the environmental circumstances in those two areas are, perhaps, causing the above difference.

The above are inductions made on the hypothesis that the whole of the neutralizing substances are developed specificially after polio virus infection. Contrary to the above hypothesis, there is the evidence, as described above, that in cattle sera there exist certain labile neutralizing substances, which disappear when stored under refrigeration more than one week within 5 months. This labile neutralizing substance is detected also by Hammon". This substance is found more frequently in baby calves than in adult cows. In one case, the existence of certain labile neutralization inhibiting substances is suspected.

However that may be, these labile substances must be taken into consideration in the discussion on the nature of inherited immunity or innate non-susceptibility.

To date, the question as to whether the whole of the neutralizing substances, which remain in the serum after months' storage under refrigeration, be assumed as specific antibodies induced by virus invasion or not is left obscure to a certain extent as yet. Because: 1) no further tests after further longer preservation had been done, 2) no conclusion could be reached that all these labile neutralizing substances are non-specific, 3) no cattle sera from the area where Lansing virus is absolutely absent was available. 
Nevertheless, probably we may suppose that these neutralizing substances remained after 1-5 months' storage are reasonably assumed to be genuine specific antibodies without serious error. It is interesting that the existence of neutralizing antibodies (stable neutralizing substances) in one case of cow's milk, and of labile neutralizing substances in 2 cases was proved.

\section{CONCLUSION}

1) Neutralization test against polio virus Lansing strain was performed with various animal sera collected in Tokyo and Hachinoe. With animal sera collected in Tokyo, 8 roof rats, 4 mice, 8 rabbits and 5 goats were all negative or equivocal, but 16 of 37 cattle, 1 of 11 horses, 2 of 6 sheep, 1 of 7 guinea pigs, 2 of 21 birds and 1 of 4 toads were positive. These positive results call for further investigations on the correlationship between epidemics and these animals.

2) When compared the positive rate of cows sera in each age group, none of 6 calves (under 1 year old), 2 of 6 cows (33\%) of 1-2 years of age, 7 of 12 cows (58\%) of 3-6 years of age, and 7 of 13 cows (54\%) of 7-11 years of age were positive. In short, positive rate in cows' sera increases generally with age.

3) Certain labile neutralizing substances, which disappear when stored in ice room for more than 1 month, exist in cows' sera. These labile substances are found more frequently and in higher concentrations in younger calves (under 1 year old) than in their mother cows. But in fact, further investigations are requisite to conclude all these labile substances to be non-specific.

4) In cow's milk, certain labile neutralizing substances, which disappear when stored one month under refrigeration, were found in 2 cases, and neutralizing antibodies (or stable neutralizing substances) were found in one case.

\section{REFERENCES}

(1) Kitaoka, M. and Miura, T.: The neutralization test of normal and convalescent human sera in Tokyo, against the mouse-adapted poliomyelitis virus "Lansing” strain. Jap. Med. J., 2, 285-294, 1949. 
(2) Kitaoka, M. and Miura, T.: Geographical distribution of neutralizing antibody against poliomyelitis virus "Lansing" strain with human sera collected in various parts of Japan. Jap. Med. J., 4, (in press) 1951.

(3) Kitaoka, M. and Miura, T.: Isolation of a new Lansing type poliomyelitis virus "B 34" strain from the feces collected from the family of a patient by using mice. Virus, 1, 31-36, 1951 (in Japanese).

(4) Kitaoka, M. and Miura, T.: The amphibia and Japanese B encephalitis virus. Sogo Igaku, 6, 717-719, 1949 (in Japanese).

(5) Hammon, W. McD., Mack, M.N. and Reeves, W.C.: The significance of protection tests with the serum of man and other animals against the Lansing strain of poliomyelitis virus. J. Immunol., 57, 285-299, 1947. 